\title{
Dermal Characteristics of the Hereditary Hairless-athymic Mouse and the Multiplication at Early Stage of Mycobacterium leprae Inoculated into the Right Hind Foot
}

\author{
Yasuko YOGI and Kazunari NAKAMURA \\ (National Institute for Leprosy Research) \\ (Received for publication: December 28, 1987)
}

Key words: Hairless-athymic mouse, nude mouse, hairless mouse, Mycobacterium leprae.

High susceptibility of the nude mice to Mycobacterium leprae as due to the absence of the thymus, namely, the hereditary incomplete immunity which was controlled by the nude gene ${ }^{(1-3)}$. When $M$. leprae were inoculated subcutaneously into the foot pad of the hairless mice, moreover, the multiplication of $M$. leprae was found to be slightly better than that in their littermate haired mice at a late stage after inoculation ${ }^{(4)}$.

Both the nude mouse and the hairless mouse are the mice of dermal mutation of hairlessness, and the skin of the hairless mouse was under the control of a recessive hereditary gene (hr) which belongs to the linkage group III ${ }^{(5)}$, while, the skin of the nude mouse was under the control of a recessive hereditary gene ( $n u$ ) which belongs to the linkage group VII ${ }^{(5)}$.

In the present study, a hairless mouse and a nude mouse were mated with an intention of knowing the influence of respective characteristics caused by the gene, which develops the skin abnormality of hairlessness, on the growth of $M$. leprae favoring the multiplication in the skin. M. leprae was inoculated subcutaneously into the right hind foot of the offspring of these matings.

The hairless-athymic mouse was a $F_{2}$ double mutant mouse which possesses the hairless gene and the nude gene at a homozygote, and was a mouse with a new dermal abnormality of developing wrinkles never observed with " $h r$ " or " $n u$ " gene alone.

\section{Materials and Methods}

Animals : $B A L B / c$ nude mice were obtained from CLEA, Tokyo and at about the same time, the hairless mice derived from ICR strain were cordially provided by Dr. K. Ezaki of CLEA. They were maintained in our laboratory by mating with the mice of several different strains. In the present study, those mated with $\mathrm{C} 57 \mathrm{BL} / 6$ and $\mathrm{CF} \# 1$ were used. The hereditary hairless-athymic mice and the nude mice were maintained in a vinyl isolator under specific pathogen-free conditions, and were provided with a sterilized autoclavable commercial diet (CE-2, CLEA, Japan Inc.) and tap water ad libitum. The other mice were housed in a conventional animal room with sterilized autoclavable pelets, water and beddings.

Mating: Female hairless mice $(h r / h r+/ t)$ of a 7 weeks old were mated with the male nude mice $(+/+n u / n u)$ of the same age to produce $F_{1}$ offsprings. Then, brother sister mat- 
ings were done to produce $\mathrm{F}_{2}$ offsprings.

Confirmation of the hairless gene and the nude gene of the hereditary hairless-athymic mouse: The male hereditary hairless-athymic mice $(h r / h r n u / n u)$ obtained as $\mathrm{F}_{2}$ were mated with the female mice of original strains $(+1++1+)$, and brother sister matings were done with the $F_{1}$ offsprings thus obtained. Four kinds of $F_{2}$ off springs were produced for the confirmation that the hereditary hairless-athymic mice were the individuals to possess homozygous hairless gene and nude gene.

Inoculation: $F_{1}$ and $F_{2}$ mice of hairless and nude matings of 4-7 weeks old and the control mice having the background of $\mathrm{C} 57 \mathrm{BL} / 6$ and $\mathrm{CF} 1$ also of $4-7$ weeks old were used for the subcutaneous inoculation of $M$. leprae derived from the nude mouse into the right hind foot in a dose of $1.0 \times 10^{6}$ bacilli.

Harvest: Following the inoculation of $M$. leprae, the animals were sacrificed at varying periods of $2,3,5,6$, and 9 months after inoculation in order to harvest the bacilli.

Identification: The acid fast bacilli (AFB) harvested aseptically were reinoculated into the right hind foot of $\mathrm{C} 57 \mathrm{BL} / 6$ and $\mathrm{CF} \# 1$ mice for confirmation of the growth pattern (persistent infection) in the mice. The obtained AFB were cultured on a $1 \%$ Ogawa's medium and a modified Nemoto's egg yolk medium at $33^{\circ} \mathrm{C}$ and $37^{\circ} \mathrm{C}$ for 6 months. Also, the AFB smears were treated with pyridine as modified by us. The tissues were fixed in buffered formaldehyde solution, and stained with Fite-Faraco, and haematoxylin-eosin.

\section{Results}

The $F_{1}$ offsprings produced by mating of the hairless female mice and the nude male mice were all haired as both of the recessive genes were heterozygous $(h r /+n u /+)$. Arbitrary brother sister matings of the $F_{1}$ mice, moreover, produced 4 kinds of $F_{2}$ offsprings as shown in Fig. 1. Namely, the appearance of genotype was controlled by the arrangement of the two recessive genes such as the nude mice $(h r /+1+n u / n u)$, hairless mice $(h r / h r n u / t /+)$, haired mice $(h \mathbf{r} /+/+\mathrm{n} u /+/+)$, and lastly, the mice with temporary unusual wrinkles having the homozygous recessive nude gene and the hairless gene simultaneously ( $h r / h r n z / n u)$. Namely, the mice which were hereditary hairless-athymic with temporary wrinkles were deficient of the thymus, and have characteristic dermal changes which vary with aging. Upon histological investigation of the skin of hereditary hairless-athymic mice which showed varying changes by aging, their hypotrichosis type change was found to belong to the cystica, and moreover, the formation of cysts changed following the advance in aging. Macroscopic discrimination of the hereditary hairless-athymic mice from the nude mice was difficult for about 10 days after birth. Abnormal dermal wrinkles of the hereditary hairless-athymic mice, however, began to appear from around 14 days after birth, namely, the period same as the appearance of depilation with the hairless mice. The wrinkles increased following the advance in days after birth, and the skin became like that of rhino mice ${ }^{(5)}$ by the time about 40 days after birth as shown in Figs. 2 and 3. Histologically, the skin at this time showed numerous cysts in both the surface layer and deep layer, especially, cyst formation in the surface layer causing the appearance of wrinkles as shown in Fig. 5. On the other hand, the wrinkles disappeared gradually 


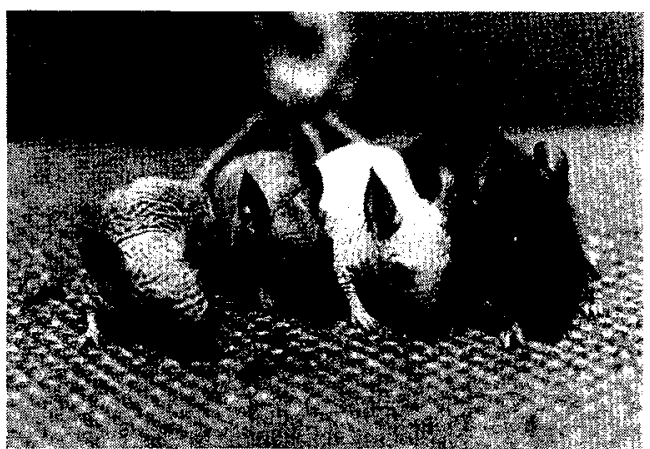

Fig. 1 Four kinds of $F_{2}$ off springs littermates were produced by mating hairless mice and nude mice. (hr/hr nu/nu), $\left(\mathrm{hr}^{\prime+} /+\mathrm{nu} / \mathrm{nu}\right),(\mathrm{hr} / \mathrm{hr} \mathrm{nu} /+/+)$ and $\left(\mathrm{hr} /+1+\mathrm{nu}^{\prime}+1+\right)$ from the left.

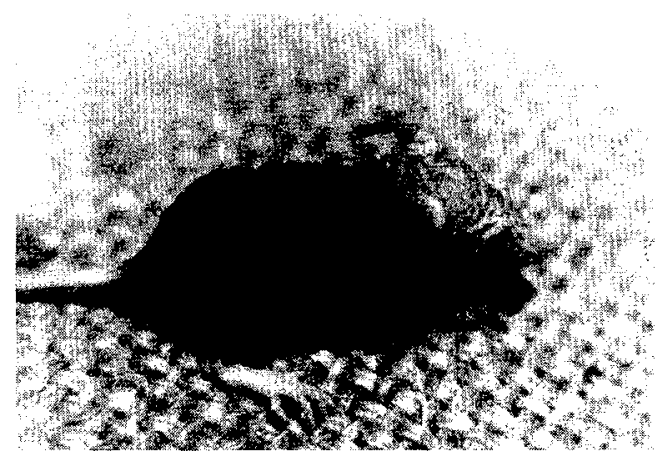

Fig. 2 Hairless-athymic mouse of 35 days after birth.

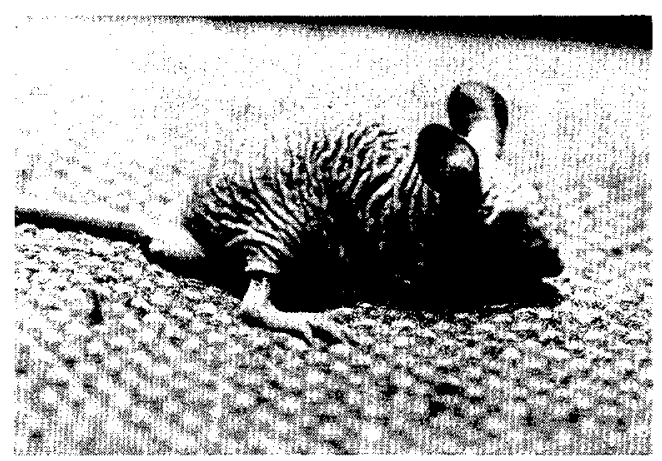

Fig. 3 Hairless-athymic mouse of 90 days after birth.

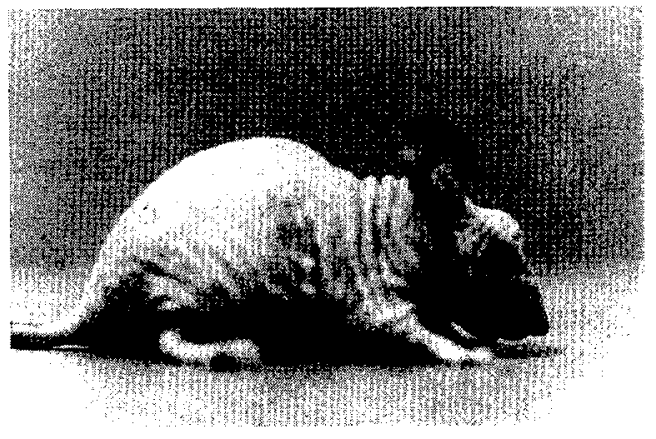

Fig. 4 Hairless-athymic mouse of 210 days after birth.

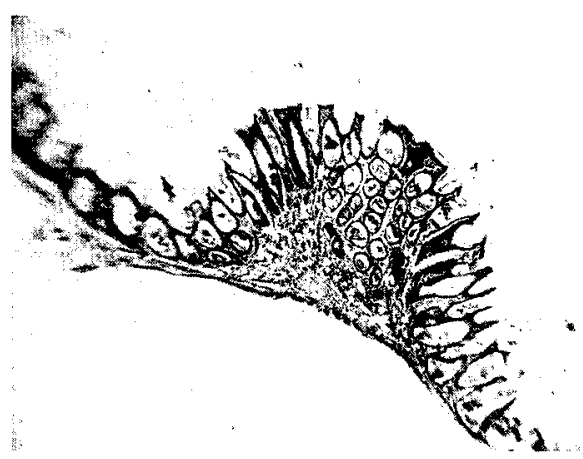

Fig. 5 Dermal histology of a hairless-athymic mouse 35 days after birth. $\mathrm{H} \& \mathrm{E}$ stain.

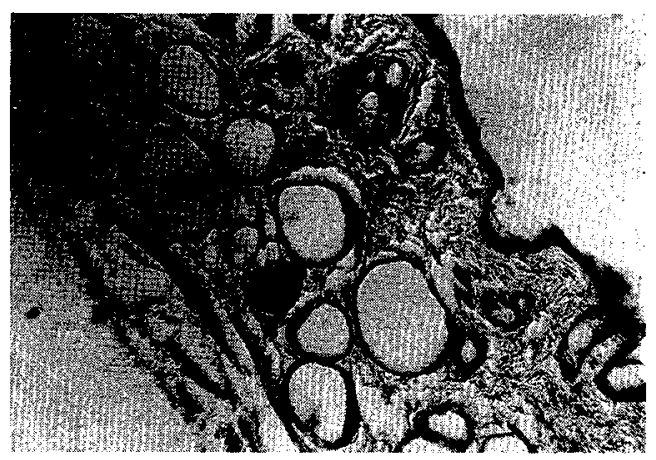

Fig. 6 Dermal histology of a hairless-athymic mouse 210 days after birth. $\mathrm{H} \& \mathrm{E}$ stain.

following the advance in thickening of the skin. By the time about 6 months after birth, the skin of hereditary hairless-athymic mice showed an appearance of the skin of hairless mice, and the cyst formation moves from the skin surface into deeper layers as shown in Fig. 6. By this time, as shown in Fig. 4 both the hereditary hairless-athymic mice and the hairless 
Table 1 Bacillary counts of $M$. leprae in hind foot of hairless-athymic mice at early stage after the inoculation

C57BL/6;

\begin{tabular}{|c|c|c|c|c|c|c|c|}
\hline \multirow{2}{*}{$\begin{array}{l}\text { Mouse } \\
\text { (back- } \\
\text { ground } \\
\text { and/or } \\
\text { genera- } \\
\text { tion) }\end{array}$} & \multirow{2}{*}{ Genotype } & \multirow{2}{*}{ Phenotype } & \multicolumn{5}{|c|}{ Months of after the inoculation } \\
\hline & & & 2 & 3 & 5 & 6 & 9 \\
\hline \multirow{4}{*}{$\begin{array}{l}\stackrel{\vec{\Xi}}{\Xi} \mathrm{F} 2 \\
\stackrel{\Xi}{\vec{a}} \\
+ \\
+ \\
+ \\
\times \\
+ \\
\end{array}$} & $\mathrm{hr} / \mathrm{hr} \mathrm{nu} / \mathrm{nu}$ & $\mathrm{H} \cdot \mathrm{A}$ & $5.8 \times 10^{5}$ & $\begin{array}{l}2.0 \times 10^{7} \\
6.0 \times 10^{7}\end{array}$ & $\begin{array}{l}3.0 \times 10^{7} \\
1.8 \times 10^{8}\end{array}$ & $\begin{array}{l}3.1 \times 10^{8} \\
5.0 \times 10^{9}\end{array}$ & $\begin{array}{l}8.5 \times 10^{8} \\
7.9 \times 10^{9}\end{array}$ \\
\hline & $\mathrm{hr} /+/+\mathrm{nu} / \mathrm{nu}$ & nude & $7.5 \times 10^{5}$ & $3.5 \times 10^{7}$ & $7.3 \times 10^{8}$ & $2.1 \times 10^{8}$ & $\begin{array}{l}6.5 \times 10^{9} \\
1.3 \times 10^{8}\end{array}$ \\
\hline & $\mathrm{hr} / \mathrm{hr} n \mathrm{n} / \mathrm{t}+$ & hairless & - & $6.5 \times 10^{6}$ & - & $\begin{array}{l}1.2 \times 10^{7} \\
4.5 \times 10^{6}\end{array}$ & $\begin{array}{l}5.5 \times 10^{5} \\
7.0 \times 10^{6}\end{array}$ \\
\hline & $\mathrm{hr} / \mathrm{t} /+\mathrm{nu} / \mathrm{t} /+$ & haired & $6.5 \times 10^{5}$ & $4.5 \times 10^{6}$ & $2.5 \times 10^{6}$ & $\begin{array}{l}3.2 \times 10^{7} \\
9.1 \times 10^{5}\end{array}$ & $\begin{array}{l}3.8 \times 10^{6} \\
8.5 \times 10^{5}\end{array}$ \\
\hline$\sum_{i=1}^{+} \mathrm{F} 1$ & $\mathrm{hr} /+\mathrm{nu} /+$ & haired & - & $1.6 \times 10^{6}$ & $\begin{array}{l}3.9 \times 10^{6} \\
8.1 \times 10^{6}\end{array}$ & $\begin{array}{l}9.3 \times 10^{5} \\
4.2 \times 10^{7}\end{array}$ & $\begin{array}{l}6.8 \times 10^{6} \\
4.1 \times 10^{6}\end{array}$ \\
\hline \multirow{3}{*}{ 芯 } & $+/+\mathrm{nu} / \mathrm{nu}$ & nude & $3.1 \times 10^{6}$ & $\cdot$ & $2.0 \times 10^{8}$ & $\begin{array}{l}5.5 \times 10^{8} \\
3.3 \times 10^{8}\end{array}$ & $\begin{array}{l}7.8 \times 10^{8} \\
6.7 \times 10^{9}\end{array}$ \\
\hline & $\mathrm{hr} / \mathrm{hr}+/+$ & hairless & $1.9 \times 10^{5}$ & • & - & $\begin{array}{l}3.1 \times 10^{7} \\
7.3 \times 10^{5}\end{array}$ & $\begin{array}{l}4.7 \times 10^{6} \\
9.2 \times 10^{5}\end{array}$ \\
\hline & $+1++1+$ & haired & • & $3.0 \times 10^{6}$ & $\begin{array}{l}2.8 \times 10^{6} \\
7.5 \times 10^{5}\end{array}$ & $\begin{array}{l}5.5 \times 10^{7} \\
6.2 \times 10^{5}\end{array}$ & $\begin{array}{l}2.5 \times 10^{6} \\
3.9 \times 10^{5}\end{array}$ \\
\hline
\end{tabular}

Note; Inoculum size $\cdots 1.0 \times 10^{6} /$ mouse

-..not tested

mice became very much alike each other macroscopically as well as histologically.

The multiplication at early stage of $M$. leprae inoculated into the right hind foot of the hereditary hairless-athymic mice and the other $\mathrm{F}_{2}$ littermate mice as well as the control mice observed for 9 months were as shown in Tables 1 and 2. Contrary to our expectation, no appreciable growth promoting effect on $M$. leprae characteristic to the hereditary hairless-athymic mice which were the double mutant of " $h r$ " and " $n u$ " genes was observable in the findings at an early stage of the observation. The findings being mostly the same as those of $\mathrm{F}_{2}$ littermate nude mice $\left({ }^{h r /+} /+n u / n u\right)$ and control nude mice $(+/+n u / n u)$, the growth promoting effect with $M$. leprae observed in the present study was considered to be derived from the deficiency of the thymus which is the characteristics of the " $n u$ " gene control.

The AFB obtained from the hereditary hairless-athymic mice and the nude mice were distinguished from other mycobacteria on the basis of the following findings: reinoculation into normal mice produced no swelling nor any other macroscopic lesions, the multiplication was confined to the site of inoculation, the cultivation on a $1 \%$ Ogawa's medium and a modified Nemoto's egg yolk medium at $33^{\circ} \mathrm{C}$ and $37^{\circ} \mathrm{C}$ for 6 months was negative, and the pyridine 
Table 2 Bacillary counts of $M$. leprae in hind foot of hairless-athymic mice at early stage after the inoculation

CF\# 1 ;

\begin{tabular}{|c|c|c|c|c|c|c|c|}
\hline \multirow{2}{*}{$\begin{array}{l}\text { Mouse } \\
\text { (back- } \\
\text { ground } \\
\text { and/or } \\
\text { genera- } \\
\text { tion) }\end{array}$} & \multirow{2}{*}{ Genotype } & \multirow{2}{*}{ Phenotype } & \multicolumn{5}{|c|}{ Months of after the inoculation } \\
\hline & & & 2 & 3 & 5 & 6 & 9 \\
\hline \multirow{4}{*}{ F 2} & $\mathrm{hr} / \mathrm{hr} \mathrm{nu} / \mathrm{nu}$ & H-A & $2.3 \times 10^{5}$ & & $1.9 \times 10^{8}$ & $\begin{array}{l}4.3 \times 10^{8} \\
8.6 \times 10^{8}\end{array}$ & $\begin{array}{l}3.2 \times 10^{9} \\
6.6 \times 10^{8}\end{array}$ \\
\hline & $\mathrm{hr} /+/+\mathrm{nu} / \mathrm{nu}$ & nude & - & $2.4 \times 10^{7}$ & $5.1 \times 10^{8}$ & $\begin{array}{l}7.2 \times 10^{8} \\
3.3 \times 10^{7}\end{array}$ & $\begin{array}{l}3.8 \times 10^{9} \\
3.4 \times 10^{8}\end{array}$ \\
\hline & $\mathrm{hr} / \mathrm{hr} \quad \mathrm{nu} /+/+$ & hairless & $\cdot$ & $3.7 \times 10^{6}$ & $7.7 \times 10^{6}$ & $\begin{array}{l}8.2 \times 10^{6} \\
1.2 \times 10^{7}\end{array}$ & $\begin{array}{l}9.3 \times 10^{6} \\
2.1 \times 10^{7}\end{array}$ \\
\hline & $\mathrm{hr} /+/+\mathrm{nu} /+/+$ & haired & $\cdot$ & $\cdot$ & $\begin{array}{l}2.9 \times 10^{5} \\
3.8 \times 10^{6}\end{array}$ & $\begin{array}{l}4.1 \times 10^{7} \\
3.5 \times 10^{6}\end{array}$ & $\begin{array}{l}6.7 \times 10^{6} \\
8.5 \times 10^{6}\end{array}$ \\
\hline 혼 & $\mathrm{hr} /+\mathrm{nu} /+$ & haired & $\cdot$ & $4.5 \times 10^{6}$ & $\begin{array}{l}1.8 \times 10^{7} \\
5.3 \times 10^{5}\end{array}$ & $\begin{array}{l}7.7 \times 10^{6} \\
8.1 \times 10^{6}\end{array}$ & $\begin{array}{l}3.2 \times 10^{7} \\
6.9 \times 10^{6}\end{array}$ \\
\hline \multirow{3}{*}{ 总 } & $+/+n u / n u$ & nude & $3.7 \times 10^{5}$ & $5.0 \times 10^{6}$ & $\begin{array}{l}2.3 \times 10^{8} \\
8.9 \times 10^{7}\end{array}$ & $\begin{array}{l}5.4 \times 10^{8} \\
2.9 \times 10^{9}\end{array}$ & $\begin{array}{l}3.3 \times 10^{8} \\
9.4 \times 10^{7}\end{array}$ \\
\hline & $\mathrm{hr} / \mathrm{hr}+/+$ & hairless & $\cdot$ & $\cdot$ & $\begin{array}{l}1.7 \times 10^{7} \\
8.6 \times 10^{6}\end{array}$ & $6.7 \times 10^{6}$ & $\begin{array}{l}1.8 \times 10^{7} \\
3.9 \times 10^{6}\end{array}$ \\
\hline & $+/++/+$ & haired & • & $3.6 \times 10^{5}$ & $\begin{array}{l}3.1 \times 10^{7} \\
8.1 \times 10^{5}\end{array}$ & $\begin{array}{l}5.4 \times 10^{6} \\
4.8 \times 10^{7}\end{array}$ & $\begin{array}{l}6.1 \times 10^{6} \\
3.9 \times 10^{6}\end{array}$ \\
\hline
\end{tabular}

Note; Inoculum size $\cdots 1.0 \times 10^{6} /$ mouse

-...not tested

extraction test showed that the acid fastness of the bacilli disappeared immediately. Thus, in view of these findings, the AFB obtained from the experimental mice were identified as $M$. leprae.

\section{Discussion}

Nude mice are known to support the growth of a large number of $M$. leprae ${ }^{(1-3)}$. On the other hand, Pattyn ${ }^{(6)}$ reported on the multiplication of $M$. leprae in the foot pad of hairless mice in 1969 . We ${ }^{(4)}$ have also reported previously that the hairless mice support the multiplication of $M$. leprae slightly better than the their littermate haired mice at a late stage after inoculation. Heiniger ${ }^{(7)}$ reported that hairless mice (HRS/J) contained Retroviridae, oncovirus (endogenous murine C-type RNA), therefore, the onset of leukemia in hairless mice was earlier and incidence was somewhat greater than in the littermate haired mice. Meier et al. ${ }^{(8)}$ reported that approximately $70 \%$ of the hairless mice developed lymphoid leukemia after 8 months of age or myeloid leukemia after 18 months of age.

In the present study, the hairless mice and the nude mice were mated with an intention of 
knowing the influence of respective characteristics caused by the gene on the growth of $M$. leprae which favors to multiply in the skin.

Appearance of the gene type in the offsprings produced by mating of the hairless mice and the nude mice was controlled by the arrangement of the two recessive genes.

The $\mathrm{F}_{2}$ offspring mice with unusual wrinkles were produced by mating the hairless mice and the nude mice. That is to say, the mice were hereditary hairless-athymic mice as they possess the two homozygous recessive nude gene and hairless gene simultaneously. The mice were deficient of the thymus and had dermal characteristics which showed changes with aging. The type of hypotrichosis was classified as cystica. The formation of cysts changed with aging, and the dermal appearance of hereditary hairless-athymic mice changed from nude mice like to rhino mice like, and then to hairless mice like as shown in Figs. 2, 3 and 4.

The multiplication of $M$. leprae inoculated into the right hind foot of the hereditary hairless-athymic mice at an early stage was mostly the same as the respective findings of $F_{2}$ littermate nude mice and control nude mice. Namely, the growth promoting effect observed in the mice was considered to be derived from the deficiency of the thymus, the characteristics of hereditary hairless-athymic mice which were the double mutant of " $h r$ " and " $n u$ " genes had nothing to do with the multiplication of $M$. leprae at an early stage. But in consideration of the fact that the detection of numerous $M$. leprae at a later stage from the skin of the nude mice which received the foot pad inoculation (eye, ear, nose, lip, loin, femur and tail), and that the favorable results observed at a later stage on the hairless mice which received the inoculation of $M$. leprae into the foot pad, we had a great expectation to know the results at a later stage of $M$. leprae inoculation on hereditary hairless-athymic mice which were deficient of the thymus and possessed the hereditary genes of both dermal abnormality and immunological abnormality with the possibility of expanding systemic dermal sites favorite to the proliferation of $M$. leprae. A separate report will be published on this subject in the near future.

\section{Summary}

The $\mathrm{F}_{2}$ mice with unusual wrinkles were produced by mating hairless mice and nude mice. The mice were hereditary hairless-athymic mice as they possess the two homozygous recessive nude gene and hairless gene simultaneously. These mice were deficient of the thymus, and the dermal appearance of hereditary hairless-athymic mice changed from nude mice like to rhino mice like, and then to hairless mice like. The type of hypotrichosis was classified as cystica. The early growth promoting effects observed on the $M$. leprae inoculated into the right hind foot of hereditary hairless-athymic mice were mostly the same as the respective findings of littermate $F_{2}$ nude mice and control nude mice.

\section{Acknowledgment}

We are grateful to Dr. K. Ezakiof CLEA, Tokyo for providing us with hairless mice. This study was supported in part by U.S.-Japan Cooperative Medical Science Program, and a report was made in Japanese in 1978. Also, outline of the present study was reported in the 51st general meeting of the Japanese Leprosy Association. 


\title{
References
}

1) Colston, M. J. and Hilson, G. R. : Growth of Mycobacterium leprae and M. marinum in congenitally athymic (nude) mice, Nature (Lond.) 262, 399-401 (1976).

2) Kohsaka, K., et al : Lepromatoid lesions developed in nude mouse inoculated with $M y c o b a$ cterium leprae, La Lepro 45, 177-187 (1976), (in English).

3) Nakamura, K. and Yogi, Y.: Systemic $M$. leprae infection in congenitally athymic (nude) mice after footpad inoculation, Res. Activ. Natl. Inst. Lep. Res. (Special Issue for the 20 th Anniv.) pp. 53-55(1975), LSM. L-784 (1976), (Personal communication).

4) Nakamura, K. and Yogi, Y. : Multiplication of $M$. leprae in hairless mice, Ann. Rep. Natl. Inst. Lep. Res. (Tokyo), 21, 24-25 (1975), La Lepro 45(2), 106-107 (1976), (in Japanese).

5) Green, M.C. : Mutant genes and linkages, pp.99-108 Green, E.L. and the staff of the Jackson laboratory (eds), In Biology of the Laboratory Mouse, 2nd ed., Dover publications, Inc., New York (1968).

6) Pattyn, S. R. : Mycobacterium leprae in foot pads of hairless mice, Int. J. Lepr. 37(2), 197198 (1969). (Correspondence)

7) Heiniger, H. J., et al.: Hereditary immunodeficiency and leukemogenesis in HRS/J mice, Cancer Res. 34, 201-211 (1974).

8) Meier, H. et al.: Genetic control by the $h r$ locus of susceptibility and resistance to leukemia, Proc. Natl. Acad. Sci. U S.A., 63, 759-766 (1969).

\section{先天性 Hairless-athymic マウスの皮膚性状 およびその右後肢足へのらい菌接種 早期の成績について}

\author{
與 儀ヤス子 中村一成 \\ （国立多摩研究所）
}

キーワード : Hairless-athymic マウス，ヌードマウス，ヘアレスマウス，らい菌

ヘアレスマウスとヌードマウスの交雑第 2 代において 皮虐に異常なしわを呈するマウスが得られた。このマウ スは，ヘアレス遗伝子座とヌード遗伝子座をホモ接合体 に持つ先天性 Hairless-athymic マウスであることが判 明した。このマウスは胸腺を久如することと, Aging と ともにその皮膚性状がヌードマウス様一ライノマウス
様一ヘアレスマウス様と変貌していく外観に大きな特徴 があり，その皮膚の Hypotrichosis type は Cystica で あった。

先天性 Hairless-athymic マウスの右後肢足へらい菌 を接種し得られた早期の成績は，同腹ヌードマウスおよ び対照ヌードマウスとほぼ同様な增殖像を示した。 


\section{編集者宛の手紙}

The Leonard Wood Memorial (American Leprosy Foundation)

is grieved by the passing of Mrs. Monina G. Madarang

on January 8, 1988.

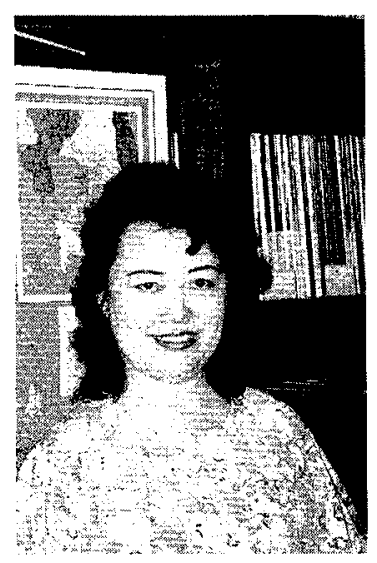

She was Administrative Director of the Cebu, Philippines facility as well as an excellent laboratory technician. Mrs. Madarang received a BS in Pharmacy from the University of San Carlos, Cebu City, Philippines, a MBA from the University of Philippines, Cebu city, Philippines. She also studied at Mercy Hospital of Medical Technology, San Diego, California and Marquette University, Milwaukee, Wisconsin.

In her 24 years of employment with the Memorial she held a variety of duties. Her wisdom and knowledge of Leonard Wood Memorial procedures in dealing with International leaders made many lasting friendships and created workable cooperation and collaboration in leprosy projects. She received specialized training in many phases of leprosy work and applied the new skills in furthering our research.

Truly committed to the leprosy cause, often giving far more then duty demanded, her caring, dedication and loyalty is truly a loss to the Memorial. 